\title{
Mısır Halk Ayaklanmalarında Sosyal Medyanın Rolü*
}

Mehmet Faiz Akpınar, Gümüşhane Üniversitesi, Halkla İlişkiler ve Tanıtım Anabilim Dalı, mfakpinar@gmail.com, ORCID: 0000-0002-0746-5121

Ali Özcan, Gümüşhane Üniversitesi, Gazetecilik Bölümü, Dr. Öğr. Üyesi, aliozcan@gumushane.edu.tr, ORCID: 0000-0003-3531-7035

$\ddot{O Z Z}$

Günümüz teknoloji dünyasında sinırların ortadan kalktı̆̆g, herkesin her yerde kolayca bilgiye ulaştığı ve bilgi ürettiği bir çağda, internet ve sosyal medyanın yeri her geçen gün daha da tartışılmaya ve konuşulmaya başlanmıştır. 2010 yılının sonlarında Tunus'ta patlak veren ve kısa sürede tüm dünyayı etkisi altına alan halk ayaklanmaları birden fazla ülkede değişikliklere yol açmıştır. Bugüne kadar söz konusu isyanlarla ilgili yapılan çalışmaların büyük çoğunluğu ise meydana gelen bu değişimleri sosyal medya endeksli ele almıştır.

Genelde Arap Halk Isyanları özelde ise Mısır isyanları üzerinden yapılan çalışmaların büyük çoğunluğu Mısır'da yaşananları "devrim" bu "devrimi" yapan asıl unsurun ise "sosyal medya" olduğunu belirtmektedirler. Nitekim yakın tarihte Orta Doğu ve Kuzey Afrika'da yaşanan isyanlarda sosyal medya ve internetin etkisi yadsinamaz. Ancak buna rağmen Arap Halk Ísyanları'nda sosyal medyanın oynadı̆̆g rol günlük hayatta herhangi bir ihtiyacımızı karşılamak için kullandığımız sıradan bir araçtan fazlası değildir.

\section{Anahtar : $\quad$ Arap Baharı, Sosyal Medya, Toplumsal Hareketler \\ Kelimeler}

\section{The Role of Social Media in the Egyptian People's Uprising}

ABSTRACT

In the modern world of technology, borders have disappeared. In an age where everyone can easily reach information and produce information. The place of internet and social media has been debated with each passing day. The popular uprisings that erupted in Tunisia at the end of 2010 and brought the whole world into effect in a short time have caused changes in more than one country. The majority of the studies conducted on these revolts up to the present day have analyzed these changes with social media index.

In general, the Arab Popular Revolts, in particular the vast majority of the work done on the Egyptian revolts, is about the revolution in Egypt. They say that the main element that makes this revolution is social media. As a matter of fact, the impact of social media and internet in the Middle East and North Africa in recent history is undeniable. However, the role played by social media in the Arab People's Revolts is not more than just an ordinary tool we use to meet our daily needs.

\section{Keywords : : Arab Spring, Social Media, Social Movements}

\footnotetext{
* Bu çalışma Gümüşhane Üniversitesi Sosyal Bilimler Enstitüsü Halkla İlişkiler ve Tanıtım Anabilim Dalı'nda tamamlanan "Yeni Toplumsal Hareketler Bağlamında Mısır Halk Ayaklanmalarında Sosyal Medyanın Rolü" adlı yüksek lisans tezinden üretilmiştir.
} 


\section{Gíriş̧}

İnsanlık tarihi insanın yerleşik hayata geçmesiyle başlayan bir süreçtir. Tarih yazıyla, yazı ise yerleşik hayata geçişle başlar. İnsanların yerleşik hayata geçmesi beraberinde yönetme, yönetilme, birlikte yaşama gibi yeni sorun ve sorumluluklar getirmiştir. $\mathrm{Bu}$ sorun ve sorumluluklara çözüm olarak ise karşılıklı özveri, hak, hukuk, adalet gibi yeni kavram ve kurumlar oluşturulmuştur.

İnsanın yerleşik hayata geçmesiyle elde ettiği yeniliklerin avantajları kadar dezavantajları da bulunmaktadır. Zira insanoğlu denetime tabi tutulmadan tek başına bırakılmayacak kadar tehlikeli bir varlıktır. Bu yüzden yönetimin teslim edildiği kişi veya kişiler halk tarafından denetlenmek istenmiştir. Bu denetim birçok kez başarılı bir şekilde yapılamasa da tarih boyunca süre gelen bir davranış olmuştur. Denetimi yapanlar ise toplumun farklı kesimlerinden ortak hedefler için mücadele eden kişiler olmuştur. Zira hiçbir düzen, her zaman ve herkes için eşit haklar sağlayamaz ve herkesi ikna edemez. Toplumun gerçekleri ile bireyin istekleri arasında sürekli bir uyuşmazlık söz konusudur. Bu da genellikle toplumun genelinin kurallarına karşı, toplumun belli bir kesiminin başkaldırmasına ve protestosuna yol açmaktadır. Parçası oldukları toplumda belli başlı konularda değişim meydana getirmek isteyen insanların oluşturduğu topluluklara ise toplumsal ya da sosyal hareketler denilir. Bu yüzden toplumsal hareketler, topluma veya yönetime yönelmiş reformcu ve inkılâpçı nitelikteki eylem biçimleridir. Söz konusu toplumsal hareketler zaman içinde büyük değişiklikler göstermekle beraber, asli görevleri olan reformcu ve inkılâpçı özelliklerini kaybetmemişlerdir. Toplumsal hareketler tarih boyunca toplumsal anlamda yaşan gelişmelere ayak uydurmuş değişimlere paralel olarak gelişim göstermiştir. Matbaadan radyo televizyona, bilgisayardan tablet ve akıllı telefon teknolojisine kadar yaşanan bütün gelişmelere ayak uydurabilmiştir. Toplumsal hareketler tarih boyunca yaşanan bu teknolojik icatları birer araç olarak kullanmıştır. Bu araçlar ise toplumsal hareketlerin hedefine varmak için hızlı ve ekonomik sonuçlar elde etmesine yardımcı olmuştur. Ancak her şey zıddıyla bilinir kaidesinden yola çıkacak olursak bu araçlar bazen de toplumsal hareketler için bu sorun ve engel oluşturmuştur. Özellikle bu araçların kontrolün gücü tekelinde bulunduranların elinde olduğunu düşündüğümüzde bu sorun daha da bariz gözükmektedir. Zira bunun en 
büyük örnekleri 2010'da Tunus'ta başlayan ve kısa sürede belli aralıklarla tüm dünyada etkisini gösteren halk isyanlarında görülmüştür. Çıktıkları toplumsal ve sosyal dinamikler göz ardı edilerek büyük oranda sosyal ağlar üzerinden değerlendirilip, tartışılmaya başlanan halk isyanlarında göz ardı edilen şey sosyal medya araçlarının toplumsal hareketlere geniş anlamda verdiği zarardır. Kısa sürede elde edilen geçici istekler üzerinden değerlendirilen sosyal medya araçları uzun süreli olarak söz konusu toplumsal hareketlere faydadan çok zarar vermiştir. Kısa süreli elde edilen istekler gerek halk isyanlarını başlatan gerekse devam ettirip, sonlandıran en önemli unsur olan; toplumsal hareketleri, sosyal ağlar karşısında ikinci plana itmiştir.

\section{ARAP HALK İSYANLARI'NDA SOSYAL MEDYANIN ETKİSI}

Arap Halk İsyanları arasından en etkili ve en çok tartışılan ülkelerin başında Mısır gelmektedir. Mısır'da meydana gelen halk isyanları büyük bir kesim tarafında 'sosyal medya devrimi' olarak tanımlandı. Bunun üzerine bilimsel makaleler, konferanslar, açık oturumlar ve sayısız haber ve söyleşiler yapıldı. Ancak gerek Arap ülkelerin genelinde gerekse Mısır'da yaşananlar ne ilkti ne de son olacaktı. Gerek Mısır'da gerekse Orta Doğu'nun genelinde meydana gelen halk isyanlarının birincil nedeni olarak sosyal medyanın gösterilmesi ve halk isyanlarının bununla isimlendirilmesi beraberinde birçok eksikliği de getirmektedir. Öncelikle sosyal medyanın etkisi inkâr edilemeyeceği gibi hiçbir zaman abartıldığg kadar olmamıştır. Genel olarak dünya üzerinde internet kullanımına baktığımızda dünya genelinde bölgesel olarak insanların internete ulaşım oranlarında büyük bir dengesizlik görülmektedir.

Tablo 1: Dünya Üzerinde Bölgesel Nüfus Bazlı İnternet Kullanıcıların Yıllara Göre Oranı

\begin{tabular}{|l|l|l|l|}
\hline Bölgeler & $\mathbf{2 0 0 0 / 2 0 0 5}$ & $\mathbf{2 0 1 0}$ & $\mathbf{2 0 1 7}$ \\
\hline Asya & $\% 8,9$ & $\% 23,2$ & $\% 48$ \\
\hline Avrupa & $\% 36,8$ & $\% 58,4$ & $\% 85$ \\
\hline Kuzey Amerika & $\% 68$ & $\% 78,8$ & $\% 95$ \\
\hline $\begin{array}{l}\text { Okyanusya, } \\
\text { Avustralya }\end{array}$ & $\% 49,2$ & $\% 61$ & $\% 68$ \\
\hline Afrika & $\% 1,8$ & $\% 11,4$ & $\% 35$ \\
\hline Orta Doğu & $\% 8.3$ & $\% 31,9$ & $\% 64$ \\
\hline
\end{tabular}




\section{Kaynak:}

2000/2005 verileri: https://www.internetworldstats.com/pr/edi008.htm

\section{0 verileri: https://www.internetworldstats.com/pr/edi061.htm}

2017 verileri: https://www.internetworldstats.com/stats.htm (Erişi tarihi: 12.09.2018)

Tablo 1'de verilen rakamlardan da anlaşıldığı üzere güç kimde ise teknolojik üstünlük de ondandır. Ya da tam tersi teknolojik üstünlük kimde ise güç ondadır. Bugüne kadar birçok kez dinlendirilen 'internet ortamı hiçbir fark ve ayırım gözetilmeksizin herkese eşit derece açıktır' söylemi söz konusu olsa da bu gün hala birçok dilde rahatça internet hizmetlerine ulaşım yapılamamaktadır. Dünyanın en çok kullanılan sosyal medya aracı olan Facebook ilk defa 2009'da Arap Halk İsyanları başlamadan 1 yıl önce Arapça versiyonu ile hizmet vermeye başlamıştır (Castells, 2013: 64).

Arap Halk İsyanları'nda internet ve sosyal medyanın kullanım oranlarına baktığımızda halk isyanların başladığı yer olan Tunus, bölgede sosyal medyanın en az etkili olduğu ülkelerden birisidir. 10.732 .900 kişilik nüfusunun 4.196.564'ünün, yani yaklaşık \%40'ının internet kullanmaktadır. Tunus'ta halk isyanlarının başladığı Aralık 2010'a kadar Facebook kullanıcısı sayısı 1.820.880 kişidir (Arab Social Media Report, 2011: a). Bu sayısı ilerleyen aylarda Mayıs 2011'de 2.356.520'ye ulaşmıştır. 2010 yılında 10.373.967 kişilik bir nüfusa sahip olan Tunus'ta Facebook kullanıcılarının oranı \%17,54'tir. Bu sayı Mayıs 2011'de 5,11 artarak ortalama Facebook kullanıcısı ortalama \%22,49'a ulaşmıştır. Tunus'ta Twitter kullanımı ise Facebook'a oranla çok daha düşüktür. 2011 Ocak ve Mart ayları arsında toplam Twitter kullanıcısı 35.746 kişidir. Bu aylar arsında günlük ortalama atılan tweet sayısı ise 6,400'dür (Arab Social Media Report, 2011: b). Tunus'ta sosyal medya Halk İsyanlarından önce birçok alanda sıkı bir takip ve engellemeye maruz kaldığı için ancak ayaklanmalar başladıktan sonra devreye girmiştir.

Libya'da da Tunus'ta olduğu gibi sosyal medya fazla kullanılmamıştır. Bunun en büyük sebebi ise rejimin internete getirdiği sansürdür. Libya'da halkı sokağa döken birincil unsurlar ise aşiretler ve dini gruplar olmuştur. Zira isyanlar başladıktan kısa süre sonra birçok rejim çalışanı isyancılara katılmıştır. Bu katılım kısa süre içinde rejimden ayrılıp isyancılara katılan 
üst sınıftaki kişilerin gücünü arttırmış, halkın etkisini azaltmıştır (Yalçıner, 2011). Libya'da soysal medyanın en yaygın kullanıldığı olay ise Kaddafi'nin ölüm görüntüleridir. Libya'da isyan esnasında pek kullanılmayan sosyal medya isyan sonrası büyük bir yaygınlık göstermiştir.

2010 yılında Libya nüfusu 6.545.619 iken Facebook kullanıcı sayısı 260,400'dir (Arab Social Media Report, 2011: a). Mayıs 2011'de ise Libya'nın nüfusu 6.670 .928 olurken Facebook kullanıcı sayısı 71,840, Twitter kullanıcı sayısı ise 63,919'dır. Libya'da günlük ortalama olarak atılan tweet sayısı ise 21,000 civarındadır (Arab Social Media Report, 2011: b). Kaddafi rejimi yıkıldıktan sonra Libya'da Facebook kullanıcı sayısı yaklaşık 317 bine ulaşmıştır. Bu yüzden Libya'da yaşananları sosyal medya ile olan ilişkisinden ziyade aşiretler ve rejim arasında ki hesaplaşma olarak değerlendirilmektedir. Zira Libya'da başlayan barışçıl eylemler çok kısa sürede aşiret liderleri ile rejim arasında bir iç savaşa dönüşmüş, sivil aktivistler devreden çıkmış, yerini silahlı örgütler almıştır.

Yemen'deki halk isyanlarında en ayırt edici özellik bu gösterilerin tamamen kültürel unsurlarla süslenmesiydi. Geleneksel şiir panayırları, geleneksel oyunlar ve geleneksel kıyafetleriyle kadınların gösterilere yoğun katılım sağlaması meydanları birer panayır havasına büründürmüştür. Yemen gösterilerinde sosyal medya kullanımı ise Mısır ve Tunus'a göre daha azdır. 2010 yılına kadar Yemen'de sosyal medya kullananlar yurt dişında arkadaşları olan elit bir kesimden fazlası değildir (Carapico, 2014: 152).

2010 yılında 24.255.928 nüfusa sahip olan Yemen'de Facebook kullanıcı sayısı 179.400'dir. (Arab Social Media Report, 2011: a) 2011 Nisan ve Mayıs ayları arasında Yemen nüfusu 24.943.950 olurken, Facebook kullanıcılarının sayısı 340,800, Twitter kullanıcılarının ise sayısı 29.422 kişiye ulaşmıştır. Günlük olarak atılan ortalama tweet sayısı ise 8,100'dır. (Arab Social Media Report, 2011: b) Arap ülkelerinde baş gösteren halk isyanları Yemen'de sosyal medya kullanımını arttırsa da Yemen, Arap ülkeleri arasında sosyal medya kullanımı en az olan ülkeler arasında yer almakladır (Arab-Social-Media-Report, 2017).

Suriye' de meydana gelen halk isyanları Mısır ve Tunus'taki gibi örgütsüz birbirinden farklı grupların oluşturduğu ya da başlattığı bir hareketten ziyade başını Suriye'nin Müslüman Kardeşler grubunun çektiği ve birçok Sünni aşiretin destek verdiği planlı ve beklenen bir 
isyandı. Arap Halk İsyanları'nın patlak vermesiyle birçok Suriyeli kesim rejimle hesaplaşmayı bekliyordu. 1982 Hama Katliamı'nı unutamayan İhvan-1 Müslim'in (Müslüman Kardeşler), Batı ve Körfez ülkelerine sürgün edilenler, solcular, küstürülmüş eski Baasçılar, zılgıt yemiş Kürtler, kısaca sistemden memnun olmayanlar ya da mağdurlar 2011'de rejimle hesaplaşma fırsatı yakalamıştır. Değişim için sokaklara çıkan barışçıl insanların çok geçmeden bazı grupların silaha sarılması, fidye için adam kaçırma olayları, mezhepçi saldırılar, infazlar, İslamcı fanatiklerin öne çıkması yüzünden Suriyeliler "yıkıl git" dedikleri rejime "diren kal" demeyi tercih etmiştir (Taştekin, 2015).

Sosyal medya araçlarının Suriye'deki halk isyanlarında çok farklı amaçlar doğrultusunda kullanıldığ1 görülmüştür. 2010 yılında 22.505.091 nüfuslu Suriye'de 241.859 Facebook kullanıcısı bulunmaktaydı (Arab Social Media Report, 2011: a). 2011 yılında ise 23.008.268 kişilik Suriye'de Mayıs ayına kadar 356,247 kişi Facebook, 40,020 kişi ise Twitter kullanmaktaydı (Arab Social Media Report, 2011: b). Kısa sürede bir iç savaşa dönüşen halk İsyanlarında sosyal medya cihatçıların ve terör örgütlerinin sıkça kullandığ gelmiştir.

Bahreyn'de başlayan halk isyanları kısa süre içinde dış güçlerin müdahalesine maruz kalmıştır. Bahreyn'de 2010 yılında 807.131 kişilik nüfus içinde 276.580 kişi Facebook kullanmaktaydı. (Arab Social Media Report, 2011: a) 2011 yılında ise 822,510 kişilik nüfusa sahip olan Bahreyn'de Facebook kullanıcılarının sayısı 302,940, Twitter kullanıcıları ise 61,896'dır. Günlük ortalama olarak atılan tweet sayısı ise 15,000'dir (Arab Social Media Report, 2011:b).

İran'da 2019 seçimleri sonrası seçimlere hile karıştığı iddiasıyla ortaya çıkan ve birçokları tarafından 'Twitter Devrimi' olarak tanımlanan Yeşil Hareket'in sosyal medya kullanım oranları çok düşük olmakla beraber İran'la ilgili atılan tweetlerin büyük çoğunluğu Farsça değildi (Gladwell, 2010). 2009 yılında İran'da sadece 19,325 Twitter kullanıcısı bulunmaktadır. Bu rakam ise İran nüfusun sadece yüzde 0.027'sine tekabül etmektedir. Ayrıca bu kullanıcılar sosyal medyaya VPN uygulaması dışında erişim sağlayamamıştır (Heaven, 2011). Öte yandan İran'da 2009'da patlak veren ve etkileri 2012'ye kadar devam eden halk isyanlarından sonra 
sosyal medya üzerinde sıkı bir sansür uygulanmaya başlanmıştır. 2009'dan 2016'ya gelindiğinde sosyal medya kullanımı büyük oranda gerilemiştir. 2012' de \%58 olan Facebook \%35'e gerilemiş, Plus kullanımı \%36'dan \%31'e, Linkedin \%12'den \%6'ya, Twitter kullanım oranı ise \%12'den \%7'ye düşmüştür (Bozorgzadeh, 2016).

Türkiye'de meydana gelen Gezi Parkı Eylemlerinde sosyal medyanın kullanımı ile ilgili olarak yapılan araştırmalara göre sosyal medyanın aktif olarak kullanıldığı ortaya çıkmıştır. Özellikle eylemlerin duyurulmasında başat rol oynamıştır. Sosyal medya gözlem ve raporlama şirketi Monitera'nın yaptığı araştırmalara göre, Gezi Parkı Eylemleri öncesinde günde ortalama atılan tweet sayısı 8 milyon civarında iken, eylemlerin başladığı 31 Mayıs ile 11 Haziran arasında günlük ortalama tweet sayısı 13,5 milyona yükselmiştir. Araştırma verilerine göre en çok kullanılan etiketler ise şu şekilde: \#direngeziparkı (2.140.709), \#direnankara (1.114.267) ve \#occupygezi (846.020) (Zelan, 2016)

\section{TWITTER VE FACEBOOK ANARŞİ Mİ, DEVRIM Mİ?}

Wall Street Eylemleri “1968 kalkışmasından bu yana, ABD'de yaşanan en önemli politik hadise" olarak kabul edilmektedir Wall Street eylemlerinde dünyanın en son teknolojileri ve en iyi internet sistemi kullanılmasına rağmen herhangi bir devrim ya da değişim yaşanmamıştır. Etkisi kitlesel ve küresel boyutlara oluşan eylem/eylemler teknolojinin merkezinde başlamıştır. Sosyal medyanın, kitle iletişim araçlarının, internetin ve ağ sisteminin en iyi olduğu yerde bu araçları kullanmayı en iyi bilenler tarafından başlatılmasına rağmen ayaklanma, başarıya ulaşmamıştır.

Castells'in Pew Institüte'nin yaptığı bir kamuoyu araştırmasından aktardığına göre Amerikalıların \%48'lik bir kesimi hareketin kaygılarını paylaşırken \%30 bunlara karşı çıkıyordu. Ancak iş taktik ve eyleme gelince \%49 buna karşı çıkıyordu (2013: 172)

2011 Ağustos'unda İngiltere'de patlak veren Tottenham BlackBerry isyanlarında sosyal medyanın etkisine değinenler olsa da, olayın gelişmesi ve yayılması ile tarihsel arkaiklerine baktığımızda sosyal medyadan ziyade, sadece BlackBerry Messenger'nin (BBM) uygulaması ağırlıklı olarak kullanıldığı görülmüştür. Bu da ne tek başına bir isyanı başlatabilir nede başarıya ulaştırabilir. Aksine sosyal medya birçok kez amacının dışında kullanılan, eylemcileri 
ifşa eden, tutuklatan bir araç haline gelmiştir. Nitekim Blackberry ayaklanmasında sosyal medya çok fazla kullanılmasa da hükümet tarafından bir ifşa ve suçlama aracı olarak kullanılmıştır. Ayaklanmanın dinamiklerine baktığımız da ise ayaklanmanın örgütlü ya da planlı olmadığı aynı zamanda herhangi bir etnik ya da siyasi amaç gütmediği görülmektedir. Nitekim olaya katılan birçok eylemcinin de belirttiği gibi olay yıllardır süren polis şiddetinin, yoksulluğun, ayrımcılığın, biriken kin ve öfkenin, ani patlamasıydı (www.acikgazete.com, 2015).

Öte yandan sosyal medyaya karşı sergilenen tutum ve tavırlar özellikle Arap Halk İsyanları ile birlikte çokça tartışılmaya başlanmıştır. Zira başta Avrupalı ülkeler olmak üzere birçok batılı ülke sosyal medyaya karşı çifte standart uygulamışlardır.

Dünyanın başka bir yerinde meydana gelen halk isyanları söz konusu birçok Batılı ülke için özgürlük hareketi olarak görülürken aynı halk isyanları kendi ülkelerinde olduğunda ise "işgal, isyan" ya da "anarşi" olarak adlandırılmış, sosyal medya ise bu "işgal, isyan ve anarşinin" sebebi olarak görülmüş̧ür. İngiltere Blackberry, ABD ise Wall Street isyanları bunun en bariz örneğidir. Zira Arap Halk İsyanları'nda sürekli sosyal medyanın ezilen halkların sesi soluğu olduğunu yaşananları ise "Facebook, Twitter devrimi" olarak isimlendiren İngiltere ve ABD yönetimi kendi ülkelerinde başlayan halk isyanlarında gösteri yapan insanlardan "Twitter çeteleri", "Facebook çeteleri" ve "düzen bozucular" olarak bahsetmişlerdir. Bu da sosyal medyanın belirleyici etkisinden ziyade Batı'nın aktif olarak müdahale edemediği olayları kendi araçlarına mal ederek gücünü ispat etmesinin başka bir göstergesidir (Özcan, 2015: 197).

\section{MISIR HALK ISYANLARI'NDA SOSYAL MEDYANIN ROLÜ}

2010'nun sonlarında Tunus' ta başlayan halk isyanları, 2011 Ocak'ında Mısır'a sıçradı. Mısır'da başlayan isyanlar, 33 yıllık Mübarek rejimine son vermiştir. Mısır tarihinde ilk defa bir başkan seçimle başa gelmiş, 1 yıl sonra yapılan darbeyle Mısır tekrar askeri rejime geri dönmüştür.

Mısır, Arap Halk İsyanları arasında en çok konuşulan ülke olmuştur. Zira Mısır askeri, stratejik, dini ve kültürel konumu açısından Arap ülkeleri arasında en önde gelen ülkedir. 
Buna ek olarak Mısır sahip olduğu 96 milyonluk nüfusu itibarıyla Arap ülkeleri arasında en yüksek sosyal medya kullanıcı oranına sahiptir. Ancak bu oran nüfusa çarptırıldı̆̆ında, Mısır'da aktif sosyal medya kullanıcı sayısının birçok Arap ülkesinden az olduğu görülmektedir. Bu nedenle Arap Halk İsyanları arasında sosyal medya etkisinin en çok tartışıldığ ülke Misır olmuştur.

Mısır Halk İsyanları'nın en çok konuşulan gruplarından biri olan ve Orta Doğu'nun en etkili sosyal medya hareketi olarak bilinen 6 Nisan Hareketi 2008 yılından beri Misır'da faaliyet göstermektedir. Hareket, sürekli eylem gösteri ve isyan çağrıları yapmasına rağmen hiçbir zaman gerçek anlamda kitleleri meydanlara toplayamamıştır. 25 Ocak'tan haftalar önce Tahrir Meydanı'nda toplanma çağrısı yapan 6 Nisan Hareketi'nin Facebook sayfasında 89,250 kişi eyleme katılacağını belirtmiştir. Ancak Stratfor istihbarat şirketinin verdiği bilgilere göre eyleme katılanların sayısı bundan çok daha azdır. Zira daha önce de belirttiğimiz gibi Mısır' da genel olarak halkın internete erişimi sınırlıydı. OpenNet Initiative internet takip şirketinin yaptığ tarihinde nüfusun \%15,4'ü internet kullanmaktadır. Bu sayı Afrika ülkelerine göre yüksek bir oran olsa da birçok Orta Doğu ülkesine göre çok düşük bir orandır. İran, Katar, BAE ve Cezayir'de internet kulanım oranları daha yüksektir (Papic ve Noonan, 2011). Hareketin çağrısına uyan kesimin büyük çoğunluğu ise örgütlü olan ve daha önce ki her eylemde aktif rol oynayan dini cemaat ve hareketlere bağlı olan gençlerdir.

Kahire'nin banliyölerinde yaşayan ve birçoğunun evinde televizyon bile olmayan insanlar, isyanlara katılmıştır. Bu insanların isyana katılmasını sosyal medya ile hiçbir alakası yoktur. Zira Kahire sokakları çoktan bir isyan havasına bürünmüştü. İnsanlar sokaktan geçenlere, balkondan seyredenlere sesleniyor, ev ev, dolaşıp insanların kendilerine katılmalarını istiyorlardı (Noujaim, 2013). Bu zamanla tüm ülkede bir domino etkisi yaratmıştır. Kahire'de sokaklara çıkmayan neredeyse kimse kalmamıştı. Ayrıca bu isyanların birde "toplumsal baskı" etkisi yaratan psikolojik bir yanı da bulunmaktadır. Günlerce ve haftalarca zulme, açlığa, baskı ve hakaretlere karşı verilen mücadeleye çeşitli nedenlerle katılmayanlar, katılmaktan çekinenler zamanla protestoların artması ve kendilerinin azınlıkta kalmalarından 
kaynaklanan psikolojik baskı ve protestocular tarafından rejim yanlısı olarak tanımlamaktan çekinerek sokağa çıkmışlardır (Abou Ouf ve Abdalla, 2011).

Bir diğer husus ise Mısır Halk İsyanları'nın sosyal medya üzerinden açılan sayfaları takip eden kişilerin sayısı üzerinden analiz yapma konusudur. Daily Telegraph gazetesinde yazarı, Heaven bu konuya "Hepimiz Khaled Said'iz" Facebook sayfası üzerinden yola çıkarak açıklık getirmektedir: “Mısır'daki 3.4 milyon Facebook kullanıcısı arasında Wael Ghonim'in "Hepimiz Khaled Said'iz" sayfasını takip edenlerin oranı nedir? Bu insanlardan kaçı o sırada ülkedeydi hiçbir fikrimiz yok. Benim İngiltere' deki Facebook hesabımı kullanarak bu sayfayı takip etmem mümkündü. Başka kaç kişi bu sayfayı Mısır dışından takip etti? Örneğin Arap diasporasındaki - Amerikan vatandaşı olmuş Mısırlı - kaç bin kişi? Bunları kimse bilmiyor."

Hraven'ın (2001) belirtiği gibi bu tür sayfalar bizlere gerçek protestocuların sayısını vermemektedir. "Hepimiz Khaled Said'iz" sayfasını 3,4 milyon kişinin takip etmesi bunların hepsinin protestolara katıldı̆̆ 1 anlamına gelmez. Zira hiçbir zaman sanal âlemdeki destek somut anlamda gerçeğe dönüşmemiştir.

Sosyal medya araştırma sitesi Sysomos'un Mısır ile ilgili atılan tweetler üzerinden yaptığ araştırmaya göre toplamda 52 milyon Twitter kullanıcısının sadece 14 bin 542'sinin yaşadığı yer olarak Mısır, Yemen veya Tunus olarak gösterdiği ortaya çıkmıştır (Berkan, 2011). Bu durum da daha önce belirttiğimiz gibi sosyal medyadaki sayısal çoğunluğun gerçek çoğunluk olmadı̆̆ını göstermektedir.

Diğer taraftan Mısır'da protestoların başladığı 2. günde internet yavaşlatılmış 3. günde ise internet telefon şebekeleri ve ulaşım tamamen kesilmiştir. Ancak buna rağmen protestolarda herhangi bir aksama yaşanmamıştır. Tam aksine 28 Şubat'ta internetin kesilmesi protestocuların üzerinde olumsuz bir etki yaratmadı̆̆ı gibi farklı alternatifler üretmelerine yardımcı olmuştur. Konuyla ilgili gerek yapılan anket araştırmaları gerekse Navid Hassanpour'un 2011'de Amerikan Siyasal Bilim Derneği'nin toplantısında sunduğu makalesinde belirttiği gibi “Cep telefonu ve internet hizmetlerinin Ocak'ta kesilmesi huzursuzluğu en azından üç önemli şekilde şiddetlendirdi. Huzursuzluktan habersiz olan ya da ilgilenmeyen birçok apolitik yurttaşı uyandırdı; yüz yüze iletişimin artmasını yani 
sokaklarda daha fazla fiziki varlık gösterilmesini zorunlu kıldı... Facebook'un kapatılması yeni kitlelere ulaşmak ve hareketi genişletmek için yeni fırsatlar sağladı." (2012: 35-36)

Ayrıca Mısır ve Tunus'ta yapılan anket çalışmalarına göre 2011 yılının başlarında halk isyanların ilk başladığı dönemde Facebook kullanıcılarının sadece \%31 bu alanı gösteri ve protestolar için kullandığını belirtmektedir. Ardından her iki ülkede internete getirilen ulaşım engellerinin protestoların devamında nasıl bir etki yarattı̆̆ı ile ilgili olarak ise; Facebook kullanıcıları (Mısır'da yüzde 56, Tunus'ta yüzde 59) internet engelinin protestoların gelişmesinde ve büyümesinde olumsuz bir etkisinin olmadığı aksine insanların daha fazla alternatif yollar keşfettiği belirtilmiştir. Bunun dışında ilk protesto hareketlerinin başladığ tarihlerde var olan Facebook kullanıcılarının sayısı ilerleyen aylarda hızla artmıştır. Özellikle isyan hareketleri bittikten sonra sosyal medya kullanımı hızlı bir şekilde artmıştır. Genel olarak Arap ülkelerinde Nisan 2010'da Facebook kullanıcıların sayısı 14.791 .972 iken olayların başladığı 2011 yılının Ocak ayında bu sayı 21.377.282'yi bulmuştur. Aradan geçen 4 ay da bu sayı 27.711.503 kişiye ulaşmıştır. 2011 yılının ilk çeyreğinde Arap dünyasında Facebook kullanıcılarının sayısı yüzde 30 civarında artmıştır (Arab Social Media Report, 2011: b). Ancak bu artışa ve olayların sıcaklığına rağmen birçok ülkede askeri yönetimler halkın kazanımlarını kısa sürede ellerinden almıştır. Artan sosyal medya kullanıcı sayısı, elde edilen eylem ve mücadele deneyimi halkın mağdurluğu vb. birçok etken, yeni bir kitlesel isyan başlatamamıştır. Bu da bize sosyal medya ya da eylem ve isyan, bilgi ve deneyimi ne kadar güçlü olursa olsun bir ülkede değişim yaratmak için yeterli olmadığını göstermektedir.

Öte yandan Mısır Halk İsyanları'nda sosyal medyanın rolünün fazlasıyla abartıldığını belirten Rabab El-Mahdi bunun “Oryantalist” bir yaklaşım olduğunu belirtmektedir. "Sanki Batı bu araçları üretmiş; biz de o araçları kullanacak kabiliyete ulaşıp kendimizi onların araçları sayesinde özgürleştirmişiz." diyen Mahdi, asıl “hikâyenin” bu şekilde olmadığını gerek Tunus gerekse Mısır'daki sosyal medya gerçeğine şu şekilde değinmektedir: “İnsanların gözden kaçırdığı şu; örneğin Tunus'ta internet kullanımının önünde birçok sınırlama var. Mısır'da devrimin başladığı zaman Facebook'a ulaşımı olan en fazla bir milyon insan vardı. Facebook üzerinden yapılan çağrılarla birkaç bin insan bir araya geliyordu. Ama ne zamanki kitlesel yürüyüşler yaptık ve fiziksel olarak sokaklarda kendimizi gösterdik, o zaman sayımız 
milyonları buldu. Sadece sosyal medyayı kullanarak örgütlemeye çalıştığımız gösteriler bir hayal kırıklığıydı." (2012)

Başta Mısır olmak üzere yakın tarihte meydana gelen halk isyanlarını daha iyi anlamak için öncelikle şu soruyu cevaplamak gerekiyor: Sosyal medya olmasaydı halk isyanları olacak mıydı? Bu konuyla ilgili Fulya Atacan şu tespiti yapmaktadır: “Deprem uzmanları gibi, görüyorsunuz ve diyorsunuz ki ‘Burada bir fay hattı var, mutlaka bir deprem olacak.' Fakat niye o gün değil de bugün oluyor? Bunu bilmiyorsunuz. Aynen depremler gibi, o toplumunda ne yapacağını biliyorsunuz ama ne zaman ne yapacağını bilmiyorsunuz." (2014: 123).

$\mathrm{Bu}$ yüzden halkın ne zaman hangi araçları ya da kanalları kullanarak ayaklanacağı ya da devrim yapacağı belli değildir. Zira Mısır ve diğer Arap ülkelerinde de aynısı olmuştur. Mısır'da yıllardır kaynayan bir tepki ve öfke seli vardı. İnsanlar yaşananlardan dolayı canlarından bezmiş bunun için en ufak bir işaret beklemekteydiler. Bu işaret ise Tunus Halk İsyanları olmuştur. Profesör Robert Mcnab’un dediği gibi “ Bu devrimler sosyal medya olmasa da olurdu. Ancak gerçekleşme hızları çok daha farklı olurdu" (2011).

\section{HALK ISYANLARINDA ETKİLI OLAN UNSURLAR}

Ortadoğu'da meydana gelen halk isyanlarına baktığımızda bu isyanlarını başını sivil toplum kuruluşları, sendikalar, öğrenci ve dini gruplar çekmektedir. Dini gruplar bazı ülkelerde bariz olarak isyanlar katılmasa da dolaylı olarak katılmıştır. Özellikle İran, Mısır, Suriye gibi ülkelerde dini grupların etkisi fazla olmuştur. İran'da 1979 da meydana gelen halk isyanlarında Bazar* esnafı ve dini cemaatler büyük rol oynamıştır (satrapi, 2007). Başta Mısır olmak üzere Arap Halk İsyanları'nda ise dini cemaatler, Cuma namazı toplanmaları ve ElCezire Televizyonu gibi unsurlar birinci derece etkili olmuşlardır. Zira genel anlamda sosyal medyayı kullananlar bir ülkenin üst ve orta sınıf insanlarıdır. Özellikle orta sınıfın yaygın olmadığı Arap ülkelerinden sosyal medya daha çok orta sınıfın üstendeki kişiler tarafından kullanılmıştır. Bu yüzden Arap Halk İsyanları'nı bir “sosyal medya devrimi” olarak anılması, yaşananların sadece sosyal medya üzerinden takip etmekten ileri gelmektedir. Zira halk

\footnotetext{
* Bazar: İran piyasasına hakim esnaf kesimi
} 
isyanlarında sokakları dolduran, toplu iş grevlerine gidenlerin büyük bir çoğunluğu açlık sınırının altında yaşayan insanlardı. Bu insanların büyük çoğunluğu günlük ortalama 1 dolar altında çalışan işçilerdi. Bu insanların sosyal medyaya ne ayıracak vakitleri ne de paraları vardı. Ancak yıllardır daha iyi yaşamak için devlete karşı direndikleri örgütlü iş sendikaları ve iş̧̧i örgütleri vardı. Bu insanları toplu grevlere getiren bu sendika ve örgütlerdi. Zira Mario Hernandez “Mübarek'in düşüşünde Mısırlı İşçilerin Rolü” adlı makalesinde, hem Mısır hem de Tunus'ta yaşanan devrim sırasında özellikle sosyal iletişim kanallarını kullanan ayrıcalıklı orta sınıfın üzerinde durulduğunu bunun ise gerçeği yansıtmadığını belirtmektedir. Hernandez, gerek Tunus'ta bin Ali hükümetini gerekse Misır'da Mübarek rejiminin yıkılmasında işçilerinin rolünün unutulduğunu belirtmektedir (Hernandez'den aktaran, Yalçıner, 2011)

Öte yandan insanların fakirliğinden yararlanan cemaat ve dini gruplar meydana en büyük kalabalıkları toplayan oluşumlar olmuştur. Zira Mısır toplumunun çok büyük çoğunluğu doğrudan veya dolaylı olarak bir cemaat veya gruba bağlı olan bir toplumdur. Bu da doğal olarak Malcolm Gladwell'in muhalefetin 'insan insana' yapılan bir etkinlik olduğunu göstermektedir. Gladwell gerek sosyal medya da gerekse meydanlarda muhalif hareketlere katılımın tanıdık ve güvendik kişi veya kurumlarca olacağını belirtmektedir. Gladwell 4 Ekim 2010 yılında New Yorker gazetesinde yazdığı makalesinde, muhalif hareketlere katılmanın bir risk barındırdığını; bu yüzden o hareketlere katılan bireylerin öncelikle söz konusu hareketin içinde tanıdığı veya güvendiği kişilere ihtiyaç olduğunu belirtmekteydi. Teknoloji ne kadar gelişirse gelişsin muhalefet 'insan insana' yapılan bir etkinliktir. Zira sosyal medyada ki insanları tanımıyoruz. Kimse tanımadıkları için büyük riskler almaz. Bu yüzden yukarda belirttiğimiz gibi gerek Mısır'da gerekse diğer Arap ülkelerinde isyanlara katılan her bireyin isyanda yer alan bir tanıdığı vardı. Aynı mahalleden, aynı sokaktan, aynı köyden aynı dernek ve sendikadan ya da aynı din, aynı mezhep veya cemaatten bir tanıdığı vardı. Bu doğrudan ya da dolaylı tanışıklık ve insanların genel mağduriyeti kitleleri meydana dökmüştür (Gladwell, 2010).

Öte yandan sosyal medyanın örgütlü yapılar karşısında gerçek anlamda bir alternatif olamamıştır. Bunu gerek Nijerya Halk İsyanları'nda gerekse Mısır Halk İsyanları'nda gördük. 
Söz konusu dini cemaat ve örgütlü gruplar gerektiğinde askerle anlaşmış ve meydandaki birçok eylemciyi yüz üstü bırakabilmiştir. Bu da doğal olarak eylem ve protestoların başarısızlığa uğramasına yol açmıştır. Nitekim Arap Halk İsyanları'ndan çıkarılan en büyük sonuç; sosyal ağ kullanıcıları ile geleneksel örgütlü yapıların işbirliği içinde olmadan bir sonuca varılamayacağı gerçeğidir. Çalışma boyunca karşılaştığımız örneklerde de görüleceği üzere lidersiz ve örgütsüz sosyal medya kullanıcıları kısa bir süreliğine ses getirseler de bu uzun süreli olamamıştır. Ancak ne zaman karşılıklı özverilerde bulunarak ortak bir payda üzerinde bir araya gelirseler o zaman rejime karşı büyük başarılar elde edebilmişlerdir. Bunun en büyük örneği Tunus Halk İsyanları'dır. Ortaya çıkmasında sosyal medyanın pek fazla etkili olmadığı Tunus Halk Ayaklanmaları zamanla sosyal medyada yaygınlık kazanmıştır. Bunun üzerine örgütlü yapılar ve dini cemaatler söz konusu sosyal medya jenerasyonuyla masaya oturmuş ve ortak paydalarda buluşabilmiştir. Söz konusu durumun aksi örneği ise 2009 yılında İran'da başlayan Yeşil Hareketi'dir. Zira Yeşil Hareket'in başarısız olmasının en büyük nedeni; hareketin soyut olarak sosyal medya üzerinden yayılması, somut olarak ise sadece Tahran ve çevresiyle sınırlı kalmasıdır. Yeşil Hareket, İran'ın orta ve işçi sınıfına, emekli ve kırsal kesimlerine ulaşamamış, örgütlü yapıların desteğini alamamıştır. Bu yüzden sınırlı bir çevrede sınırlı bir etkiye sahip olmuş rejim tarafından marjinal ve 'dış güçlerin maşası' olarak suçlanmıştır. Mısır'da ise protestocular internet, ulaşım ve şebeke kesintilerine rağmen eylemlerini genişletmiş ve devam ettirmişlerdir. Bu da bizlere bir hareketin, bir eylemin sadece sosyal medyayla başarılı olamayacağını göstermektedir.

\section{ARAP HALK ISYANLARINDA SOSYAL MEDYANIN ÖN PLANA ÇIKARILMASI VE HALK İSYANLARI ÜZERINDEKI ROLÜ}

Arap Halk İsyanları'nda sosyal medyanın Batı tarafından ön plana çıkarılmasının en büyük nedenlerinden biri de dünyanın geri kalanını yerinde takip etmeyip, sosyal medya üzerinden izlemesinden kaynaklanmaktadır. Zira söz konusu Avrupa kıtası dışında bir yer olunca Batı, burada meydana gelen olaylar yerinden izlemek yerine daha çok uzaktan, sınırlı bir kesim tarafından kullanılan sosyal medya aracıyla takip etmeye çalışmaktadır. Nitekim bu bölgelerde izlediği politikalar birçok kez Batı'nın bu bölgelerde birinci elden gözlemci olarak 
olayları izleme fırsatını ortadan kaldırmıştır. O yüzden İran'da meydana gelen 'İslam Devrimi' ne 'Kaset Devrimi' Yeşil Hareket'e 'Twitter Devrimi' demesinin en büyük nedeni de bu olayları sosyal medya üzerinden takip ediyor oluşundan kaynaklanmaktadır. Söz konusu bu sorun, sadece Batı'yla sınırlı değildir. Aynı sorun Türkiye içinde geçerlidir. Gerek Mısır Halk İsyanları'nda gerekse Tunus'ta gerekse diğer Arap ülkelerinde meydana gelen isyanları Türkiye medyası muhabir gönderip, yerinden takip etmek yerine Batı medyası gibi sadece sosyal medya ya da tek taraflı kanallardan izledi. O yüzden gerek yaşananları tanımlamada gerekse yaşananlara karşı attığı adımlarda büyük hatalar yapmıştır.

Halk isyanlarında sosyal medyayı popüler kılan bir başka etken de ana akım medyanın pasifliği ve iktidar korkusu olmuştur. Zira ana akım medyada yer bulmayan eylemciler zorunlu olarak sosyal medya kaymış, ilerleyen zamanlarda halk isyanlarına karşı daha fazla kayıtsız kalamayan ana akım medyası olayları yerinden islemediği ya da izleyemediği için kaynak olarak sosyal medyaya yönelmek zorunda kalmıştır.

Bugün 'sosyal medya, Facebook, Twitter devrimi' gibi konuları tartışmamızın en büyük nedenlerinden birisi de Batı'nın özellikle Doğu'da yaşanan gelişmelerde sosyal medyanın etkilerini abartmasından kaynaklanmaktadır. Zira bunun ilk örneği 1979 "İslam Devrimi" ardından 2009'da İran Cumhurbaşkanlığı seçimlerinde meydana gelen protestolarda görülmüştür. "Yeşil Devrim" olarak isimlendirilen protestolar batı tarafından "Twitter Devrimi" olarak tanımlandı. Zira Washington Times, $C N N$ ve BBC gibi küresel medya kanalları İran'da yaşananları bu isimle vermekteydi. Bu nedenle İran'da muhalefetin doğal olarak sosyal medyayı kullanması manşete çekildi ve bu isimle anılmaya başlandı. Medyanın kullandığı popüler dili zamanla akademiden kişiler de kullanmaya başladı. Zira İran'da meydana gelen protestolarla ilgili olarak ABD'li yazar ve internet Uzmanı Clay Shirky “Bu sosyal medyanın küresel dünya sahnesine fırlattığı ilk devrim." tabirini kullanmıştır. Ancak göz ardı edilen en önemli konu ise İran'da 2009 yılında sadece 19,325 Twitter kullanıcısı olduğu (nüfusun yüzde 0.027si) olduğu gerçeğiydi. Zira İran'da yaşananlardan bir yıl sonra Global Voices'in İranlı editörü Hamid Tehrani yaşananlarla ilgili olarak şu açıklamalarda bulunmuştur: “Batı İran halkından ziyade Batı teknolojisinin etkileri üzerinde odaklandı... Twitter sadece neler olduğunu yaydı, ama rolü fazlaca abartıldı”. İstisnasız İran'da 
yaşananların aynısı Mısır ve diğer Arap ülkeleri örneğinde yaşanmıştır. Zira Mısır'da ilk protestolar başladığında CNN kanalı Ghanim'in "Bu bir İnternet devrimidir. Ben buna “2.0 Devrimi diyorum" açıklamalarını vermiştir. Hemen ardından Newsweek dergisi Wael Ghonim'i “Facebook özgürlük savaşçısı" olarak tanıtırken, New York Times gazetesi ise "Wael Ghanim'in Mısır'1" başlığı atmıştır (Heaven, 2011). Olaylar Google temsilcisi üzerinden sosyal medya ve internete bağlanmaktaydı. Çok kısa süre içinde Mısır'da ve tüm Arap ülkelerinden yaşananlara kendilerince birçok isim bulunmuştu. “Arap Baharı, Sosyal medya, Facebook Devrimi" gibi. Ancak bu isimler bizzat meydanlarda sokaklarda mücadele edenlerin kullandığı isimler değildi. Aksine sürekli olduğu gibi birileri onları istedikleri gibi görmek istediği için onlara bu isimleri takmaktan geri kalmamıştı. Vijay Prashad'ın belirttiği gibi “Amerikancılığın tuhaf dişavurumlarından birisi her bir dinamiğin denetimini kendi ellerine almaya çalışma girişimidir." Zira Prashad da Orta Doğu ve Kuzey Afrika'da yaşanan halk ayaklanmalarının başta Amerika olmak üzere batılı kurulu düzen medyası tarafından manipüle edildiğini belirtmektedir: "Tunuslular ve Mısırlılar ayaklandılar; Amerika Birleşik devletlerindeki kurulu düzen medyası bunun onurunu Kuzey Afrika'nın sıradan halkına değil de Facebook'a veya Obama'nın 2009'da Kahire konuşmasına* ya da düşünür Gane sharp'ın kitabına vermek istediler... Elbette Facebook okuryazarlar arasında örgütlenme çalışmalarına bazı yaratıcı katkılar yaptı, ama önemli değil” (2012).

Halk isyanlarının altında yatan etken; sosyal medyanın aktif veya pasif olarak kullanılması değildir. Öncelikle toplumun tüm kesimlerinin gerçekten bir devrim ya da değişim isteyip istemediği, isteğin muhatapları olan iktidarların ve arkalarındaki iç ve dış güçlerin bu değişime nasıl baktıklarıyla ilgilidir. Bu iki seçenek olumlu anlamda gelişir ve bu istekler doğrultusunda bir araya gelen kitleler sonuna kadar isteklerinin yerine gelmesinde israr ederlerse; ancak o zaman bir devrim ya da değişim gerçekleşebilir. Aksi durumda yakın dönemde dünyanın dört bir tarafında meydana gelen halk isyanları gibi geçici bir 'karnaval havası' olur. Castells'in Wall Street hareketi için yaptı̆̆ı tespitler yakın dönem halk

\footnotetext{
* Obama Kahire'de “ sıkılı yumruklarınızı açmaya istekliyseniz, size elimizi uzatacağız” demişti. Tahrir Meydanı'ndaki protestocular ise "elimizi uzatıyoruz niçin yumruklarınızı sıkıyorsunuz" diyerek Obama'nın ayaklanan Mısır halkının mücadelesine karşı sessizliğini eleştiriyorlardı.
} 
isyanlarının birçoğu içinde geçerli sayılmaktadır. Wall Street hareketi belli politikaları desteklemek için bir araya gelmediği için hareketin eylemleri de büyük bir politika değişikliğine yol açmamıştır. Hareket somut talepler elde etmek yerine realitede karşılığı olmayan 'arzu edilene ulaşmak isteği' hareketin ölü doğan bir sinizim ile bitmesine yol açmıştır. Castells'in deyimiyle hareketin "hiçbir talebi yoktu, ancak bütün talepleri vardı." (2013: 166).

“Biz yüzde 99'uz" sloganının mucidi anarşist antropolog David Graeber "Bir eylemin gerçek olması için gerçek sahada örgütlenme yapmalısınız" demektedir. Genelde Arap Halk İsyanları'nda özelde ise Mısır' da nisbi değişimi getiren etkenlerden birisi de, yapılan çağrıların beraberinde milyonları sokaklara ve meydanlara çıkarmasıydı. Wall Street eylemlerinde ise sosyal medyada milyonlarca insanın destek vermesine rağmen sokağa çıkanların sayısı 10 bini geçmemiştir (Özdemir, 2015).

İşgal eylemlerinde sosyal ağların çok iyi kullanılması ve bu mecralarda gösterilen yoğun destek fiziksel bir katılıma dönüştürülemedi. Zira bir eylemcinin de belirttiği gibi “İnternet insanları dikizciliğe alıştırdı. İnsanların hareketi uzaktan seyretmelerini, şahsen içinde hiç yer almaksızın her gün yakından izlemelerini sağladı." (Castells, 2013)

Öte yandan internet ve sosyal medyanın etkisi ele alınırken muhakkak o ülke ve bölgelerde ki yönetim şekillerine o yönetimlerin internet ve demokrasi ile olan ilişkilerine bakılmalıdır. Zira Arap coğrafyası ya da genel anlamda Orta Doğu'yu ele aldığımızda karşımıza bir dizi otokratik ve diktatöryal yönetimler çıkmaktadır.

$\mathrm{Bu}$ yönetimlerin en büyük korkusu halkın demokrasi isteme korkusudur. Bu yüzden bu isteklerini dile getirebilecekleri her yolu engellemek için tüm imkânlarını seferber ederler. Son zamanlarda bu seferberliğin başında internet ve sosyal medya kullanımının sınırlanması ve kontrol altında tutması gelmektedir. Zira gerek isyanların ilk başladığı Tunus'ta gerek Libya ve Mısır'da gerekse diğer ülkelerde internet üzerinde büyük sınırlamalar ve baskılar bulunmaktaydı. Bu yüzden internet ve sosyal medya kullanımı belli bir kesim ile sinırlı kalmıştır. Söz konusu bu ülkelerde sosyal medya isyanların başlangıcında insanların büyük çoğunluğuna ulaşamamış büyük kitleleri toplama imkânına sahip olamamıştır. Kısacası bir ülkede internet ve sosyal medya kullanıcılarının fazla olması o ülkede meydana gelen 
değişimlerin üzerinde bu mecraların büyük bir etkisi olduğu anlamına gelmemektedir (Heaven, 2011).

Öte yandan sosyal medya özgür ortamlarda neredeyse halkın tamamını sanal âlemde bir araya getirebilecek geçici bir özelliğe sahiptir. Ancak ne zaman bu özgürlükler kısıtlanmaya başlansa o zaman sanal âlemde bile bir araya gelen kişilerin sayısı büyük bir düşüş göstermektedir. Sosyal medyanın birleştirici ve harekete geçirici gücü demokrasi ve özgürlükle orantılıdır. Sanal ortamda birleşen kesimler genel anlamda siyasi veya dini bir kimliğe sahip olan kişi veya kişilerdir. Son zamanlarda bu kesimlerin en aktif olanı gerçek anlamda radikal siyasi veya ideolojik bir dünya görüşüne sahip olmayan ancak içinde doğdukları sanal ağlardan hiç ayrılamayan yeni nesil olmuştur. Bu neslin en ayırt edici özelliği ise sabırsız ve hızlı yaşamasıdır. Sosyal ağlar ile hayata başlayan bu nesil, kalıcı etkili bir muhalefetten ziyade daha çok hızlı ve reformist değişiklikleri tercih ederler. Arap Halk İsyanları'nın başlangıcında, Occupy Wall Street ve Öfke Hareketlerinde olduğu gibi.

O yüzden sosyal medya veya ağlar üzerinden başlatılan bu araçlarla hedefe ulaşmaya çalışan hareketler genellikle kısa ömürlü olmuşlardır. Nedeni ise sosyal ağların hiçbir zaman gerçek anlamda sanal âlemdeki kitleyi meydanlara sürememesidir. Halkı meydanlara süren en etkili unsurlar temel yaşam şartlarının sekteye uğramasıdır. Bu şartların sekteye uğraması veya ortadan kaldırılması er ya da geç halkın tepkisine maruz kalacaktır. Bunun önünde ve arkasında hiçbir araç duramaz. Victor Hugo'unun deyimiyle “Zamanı gelmiş bir fikrin karşısına dikilme gücüne hiçbir ordu sahip değildir." Bu yüzden Arap Halk İsyanları zamanı gelmiş bir fikrin vücut bulmuş halidir. Bunun ne zaman ve nasıl ortaya çıkacağı kestirilemez ise de, kaçınılmaz olduğu gün gibi aşikâr olan bir durumdu.

\section{SONUÇ}

Sosyal medya hareketin ekonomik ve enerji masraflarını minimize eder, hareketin eylemlerini hızlandırır. Ancak tek başına hiçbir değişim yapma gücüne sahip değildir. Sosyal medya üzerine kurulacak bir eylem veya protesto hareketinin başarılı olma şansı neredeyse sıfırdır. Zira bu açıkça rejimin gözetimi altında olan bir alanda rejime karşı eylem yapmak olur. Hükümetler sıkı takip altında tuttukları muhalif grupları 24 saat izleyebilmektedirler. Nerede, 
ne zaman, nasıl toplanacaklarını anında öğrenebilir ve eylemciler alana toplanmadan binlerce polis ve asker alanı işgal edebilir. Bu da planlanan eylemin başarılı olma şansını en aza indirir. Bunun yanında hareket liderlerinin tutuklanması, işkence ve tehditlerle caydırılması da söz konusu olabilir. Birçok sosyal medya aracı bir ülkede faaliyet gösterebilmek için o ülkenin hükümetleriyle bilgi alışverişi yapmak için anlaşma yapmaktadırlar. Yapılan bu anlaşmalar sonucu kullanıcıların bilgilerine, konumlarına ve ağ bilgilerine erişmek çok daha kolay hale gelmektedir. Zira Mısır'da eylemler sırasında daha önceden bilgilerine ulaşılan ve açığa çıkartılan 6 Nisan Hareketi'nin 40 lideri tutuklanmış. Aralarından Esra Abdel Fettah Ahmet Raşid, adında bir kadın işkenceye maruz kalmış ve tutuklanacağını bilse böyle bir yola başvurmayacağını açıklamıştır. Bu ve buna benzer durumlarda geri kalan sosyal medya kullanıcıları üzerinde bir korku ve vazgeçme nedeni olabilir. Ya da en kötü senaryo olarak 28 Ocak'ta Mübarek'in yaptığı gibi tamamen internetin fişi çekilebilir. Bu da sosyal medya üzerinden çıkan hareketleri büyük bir sıkıntıya sokabilir.

Ayrıca sosyal medyaya baktı̆̆ımızda neredeyse her konuda açılan sayfalar oluşturulan hareketler vardır. Günlük olarak birçok konu hakkında Hastag (etiketler) açılır ve bu konulardan bazıları Trend Topic (TT) (gündem) olabilir. Oluşturulan bu gündemler ne kadar popüler olursa olsun bir devrim oluşturamazlar. Zira dünyanın dört bir tarafındaki internet kullanıcılarına açık olan bu alan herkes tarafından kullanılabilir. Çin'deki bir sosyal medya kullanıcısı anlamadığı bir dilde açılan bir etiketi paylaşabilir, ya da beğenebilir. Tüm bu bilgilerden yola çıkarak Mısır'da yaşananların bir sosyal medya hareketi ya da bazılarını belirttiği gibi bir "sosyal medya" devrimi olmadığını söyleyebiliriz. Zira eğer hareket bir sosyal medya hareketi olsaydı 5 günlük internet, ulaşım ve şebeke kesintisiyle sona ererdi. Ancak Mısır isyanlarına baktığımızda isyanların en kalabalık olduğu anlar internet, şebeke ve ulaşımın kapatıldığı anlar olduğunu görüyoruz. Bu da bize Mısır'daki yaşananların bir sosyal medya hareketi olmadığını, tam aksine sosyal medyayı birçok araçtan sadece biri olarak kullanan örgütlü oluşumlardan oluşan hareketlerin başlattığı ve bitirdiği bir eylemler zinciri olduğunu göstermektedir. Mısır özelinde bu örgütlü yapılar dini cemaatler, Cuma namazı çıkışları ve neredeyse her Mısırlının evinde izlenen El-Cezire Televizyonudur. 
2011 yılında başta Orta Doğu ve Kuzey Afrika olmak üzere dünyanın dört bir tarafında baş gösteren halk isyanları o günün şartlarında olayın sıcaklığıyla büyük oranda sosyal medyaya mal edilmiştir. Ancak 2018'de geriye dönüp baktığımızda sosyal medyanın toplumsal konularda istenilen değişimleri sağlamadığını; bunun aksine daha kötü durumların ortaya çıktığını görmekteyiz. Orta Doğu ve Kuzey Afrika gibi tek adam yönetiminin var olduğu ülkelerde sosyal medyanın çözüm olmadığı gibi ilerleyen yıllarda büyük sıkıntılara da yol açtığını görmekteyiz. Özellikle bu mecrayı, söz konusu rejimlerin kullanması ve bu alanda halkı gözetip denetim altına alması, var olan toplumsal muhalefetinde sindirilmesine yol açmıştır. Zira toplumsal konularda bir değişim gerçekleşebilmesi için sadece tepki vermek yeterli olmuyor. Toplumsal değişimlerin sağlanmasında ülkeler arası dengeler, ülkenin jeopolitiği, toplumsal sosyoloji ve uluslararası ilişkiler en büyük etkenlerdir. İletişim teknolojileri her ne kadar gözle görünür düzeyde yüksek olsa da sonuca varma konusunda başat etken olamamaktadır (Pesen , 2017).

Sosyal medya tek başına devrim yapabiliyorsa neden en katı diktatöryal yönetimlerin olduğu ülkelerde bu görevi yerine getiremiyor? Çin, Kuzey Kore, İran, Suudi Arabistan, Katar veya Afrika'nın birçok ülkesinde söz konusu sosyal ağlar mevcut diktatörleri deviremiyor. Ya da en günceli 8. yılına giren Suriye Halk İsyanları neden Esad'ı deviremedi. Başta ABD, AB, Türkiye ve birçok bölge ülkesi muhaliflere destek vererek devirmeye çalıştıkları Esad, neden bugüne kadar devrilemedi? Ya da tam tersi neden sosyal medya en yüksek ve en nitelikli kullanıcı kitlesine sahip olan "demokratik" ülkelerde bir devrim ya da köklü değişim yapamıor? ABD, İngiltere, Fransa gibi ülkelerde neden bir sosyal medya değişimi ya da devrimi tüm çabalara rağmen gerçekleşemiyor?

Tüm bunların yanında Mısır'da Mübarek'in devrilmesi sadece sokaktaki halkın tarafından istenilen bir şey değildi. Aynı zamanda Mısır’ın en etkili ve en kutsal gücü sayılan asker ve askeri besleyen ülkelerde Mübarek'in gitmesinden yanaydı (Ayhan, 2011). Kısaca, genelde Arap coğrafyasında özelde ise Mısır'da yaşananlar sadece birkaç sebepten dolayı gelişen olaylar değildir. Tam aksine birçok nedenin bir araya gelmesiyle yaşanan gelişmelerdir. Bu yüzden Orta Doğu ve Kuzey Afrika'da yaşanan bu halk hareketlerini sınırlı nedenlerle 
açıklamaya çalışmak ve belli başı araçlara mal etmek yaşananları eksik veya yanlış anlaşılmasına yol açar.

Lübnanlı yazar Amin Maalouf, Arap halkını tanımlarken “Her şeye üzülen ama hiçbir şeyle ilgilenmeyen insanlar" tanımını yapmaktadır. Arap Halk İsyanları her şeye üzülen halkın, gerektiğinde çok şeyle ilgilenebileceğini de göstermiş oldu. John Holloway'ın da belirttiği gibi bugüne kadar yukardan gelen değişimlere karşı ilk defa bu büyüklükte bir değişim hareketi sokaklardan neşet etmiştir. Bu hareket ise "hiçbir şeyle ilgilenmeyen insanların" sarsılmaz olarak görülen diktatörleri kâğıt kaplan gibi devirmiştir. Kısaca “Bu sefer öfke sokaktan sarayı titretmiş, değişimi başlatmıştır."

O yüzden son olarak Gil Scot Heron'nun belirttiği gibi “devrim televizyondan” ya da sosyal medyadan- yayınlanmayacak, devrim canlı olacak." Eğer Orta Doğu ve Kuzey Afrika'da bir değişim ya da bir devrim olacaksa bunu televizyon ya da sosyal medya yapmayacak, bizzat halkın kendisi yapacaktır. Zira yakın tarihte meydana gelen halk isyanları'nda sosyal medya kullanım oranlarına bakıldığında sosyal medyanın tek başına bir değişim ya da 'devrim' yapacak güçte olmadığı anlaşılmaktadır. Bu unsur Arap Halk İsyanları etkisi altında kalan diğer ülkelerde de görülmektedir. Örneğin Nijerya, ABD, İngiltere, İran ve Türkiye'de meydana gelen halk İsyanlarında sosyal medya tek başına belirleyici bir unsur olamamıştır.

Sonuç olarak her dönemim kendine özgü iletişim araçları vardır, bu araçlar ise amaçlar için kullanılır, bu da aracı amaç kılmaz. Tunus'ta başlayan ve tüm Arap coğrafyasını saran bu halk ayaklanmaları bir sosyal ve dijital medya devrimi değil olsa olsa bir "uyanış ve/veya haysiyet" devrimidir.

\section{KAYNAKÇA}

ABOU OUF Mariam ve ABDALLA Ahmet; (2011), "18 Gün" https://www.youtube.com/watch?v=EUvp37OacdA Erişim Tarihi: 05.08.2018

AÇIK GAZETE; (2015), “2011 Londra Ayaklanması'nın anotomisi”, https://www.acikgazete.com/2011londra-ayaklanmasnn-anotomisi/, Erişim Tarihi: 11.04.2018. 
ARAB SOCIAL MEDİA REPORT; (2011), "Facebook Kullanımı: Faktörler ve Analiz", http://www.arabsocialmediareport.com/UserManagement/PDF/ASMR\%20Report\%201.pdf.Er işim Tarihi: 22.06 .2018

ARAB SOCIAL MEDİA REPORT; (2011), "Arap Sosyal Medya Raporu", http://www.arabsocialmediareport.com/UserManagement/PDF/ASMR\%202\%20Arabic\%20Fin al.pdf. Erişim Tarihi: 22.06.2018

ATACAN Fulya; (2014), "Mısır'da 25 Ocak Devrimi'nin Arka planı: Ekmek, Hürriyet, Adalet", iç. Zahide TUBA K. (Ed.), Ortadoğu Konuşmaları, Küre Yayınları, İstanbul, ss. 103-133.

AYHAN Veysel; (2011), “Misır Devriminin Ayak Sesleri”, Ortadoğu Analiz dergisi, 3 (26), ss.15-26.

BERKAN İsmet; (2011), "Halkın Sesini Dinle Üstüne Su ve Gaz Sıkma", http://www.hurriyet.com.tr: http://www.hurriyet.com.tr/halkin-sesini-dinle-ustune-su-ve-gaz-sikma-16931475, Erişim Tarihi: 25.07.2018.

BOZORGZADEH Amir E.; (2016), “Dijitalleşen Iran'ın Durumu”, https://techcrunch.com: https://techcrunch.com/2016/01/29/the-state-of-digital-in-iran/, Erişim Tarihi: 25.07.2018.

CARAPICO Sheila; (2014), "Yemen”, iç. Paul. AMAR ve Vijay PRASHAD, (Ed.), Arap Baharı'ndan Kesitler- Yeni Orta Doğu'yu Anlamak, İntifada Yayınları, İstanbul, ss. 149-173.

CASTELLS Manuel; (2013), İsyan ve Umut Ağları-Internet Çă̆ında Toplumsal Hareketler,Çev: Ebru Kılıç, Birinci Baskı, Koç Üniversitesi Yayınları, İstanbul.

EL-MAHDİ Rabab; (2012), "Arap Baharı Denmesinden Nefret Ediyorum", https://bianet.org/kurdi/dunya/135427-arap-bahari-denmesinden-nefret-ediyorum , Erişim Tarihi: 05.09.2018.

GLADWELL Malcolm; (2010), "Küçük Değişim Devrim Neden Twitlenmeyecek", https://\%20/magazine/2010/10/04/small-change-malcolm-gladwell , Erişim Tarihi:23.07.2018.

HEAVEN Will; (2011), "Mısır ve Facebook'un Statüsünü Güncelleme Zamanıdır", https://www.nato.int/docu/review/2011/social_medias/Egypt_Facebook/TR/index.htm, Erişim Tarihi: 06.02.2018. 
MCNAB Robert; (2011), "Sosyal Medya: Insanlara Güç Kazandirlyor Mu?", https://www.nato.int/docu/review/2011/social_medias/Social_media_can_do/TR/index.htmEri şim Tarihi:12.09.2018.

NOUJAİM Jehane; (2013), “Meydan”, https://jetfilmizle.vip/meydan-al-midan-turkce-dublaj-izle.html, Erişim Tarihi: 19.06.2019

ÖZCAN Ali; (2015), "Sosyal Medyanın Ekonomi Politiŭïi", iç. Ramazan ÇELIKK ve Sertaç DALGALIDERE (Ed.), Yeni ve Geleneksel Medya Okumaları İskenderiye Yayınları, İstanbul. ss. 185-198.

ÖZDEMIR Önder; (2015), "Başarısız Bir Sosyal Medya Deneyimi: Occupy Wall Street", http://sendika62.org/2015/01/basarisiz-bir-sosyal-medya-deneyimi-occupy-wall-street-onderozdemir-241295/, Erişim Tarihi: 15.02.2018.

PAPIC Marko, ve NOONAN Sean; (2011), “Sosyal Medya: Bir Protesto Aracı”, Çev, Ece Dündar, Türk Kütüphaneciliği dergsi, 25, (1), ss.165-172.

PESEN Mekin;(2017), “ Sosyal Medya Devrimlerinin Anatomisi", Erişim Tarihi: 07. 24. 2018. https://www.esiber.com/sosyal-medya/sosyal-medya-devrimlerinin-anatomisi/ , Erişim Tarihi: 26.05.2018.

PRASHAD Vijay; (2012), Arap Baharı Libya Kışı, Çev: Şükrü Alpagut, Birinci Baskı, Yordam Kitap, İstanbul.

SATRAPI Marjane; (2007), "Persepolis", https://www.altyazilifilmizle.pw/persepolis-izle.html , Erişim Tarihi: 19.05.2019

TAŞTEKINN Fehim; (2015), Suriye: Yıkıl Git, Diren Kal!, Beşinci Baskı, İletişim Yayınları, İstanbul.

YALÇINER Mustafa; (2011), "Libya'da Ayaklanma ve Emperyalist Müdahale", iç. Mustafa YALÇINER (Ed.), Arap Dünyasında Ayaklanma, Evrensel Basım Yayınları, İstanbul, ss. 240-255.

ZELAN Zeynep; (2016), Hareketler ve Yeni Medya Okuryazarlı̆ğ Castells'in Ağ Toplumu Kuramı Bağlamında Toplumsal Yeni Medya Çalışmaları, Alternatif Bilişim Derneği, İstanbul:, ss. 483-495. 